\title{
Development of Plant Tissues Atlas for Instructional Media at Senior High School
}

\author{
Ardi $^{1}$, Yudi Agustira Rahmatullah ${ }^{2}$ \\ \{ardibio@fmipa.unp.ac.id $\left.{ }^{1}\right\}$ \\ Biology Department of Universitas Negeri Padang ${ }^{1}$, Graduated Program of Biology Department of \\ Universitas Negeri Padang ${ }^{2}$
}

\begin{abstract}
Biology learning requires students to carry out observations in practicum activities to form of concept understanding. In the other hand some microscopes had moldy lenses, and the unavailability of practical guidance media that contained photographs of plant tissue observations slashed manually. This development research using tree stages from the 4D development model, namely definition, design and development. The instruments were used interview guides, validity and practicality questionnaires. The validity test results obtained an average value of 3.73 . with very valid criteria from the aspects of the appropriateness of content, language and readability, and presentation. Practicality test results obtained an average value of 3.81 with very practical criteria by teachers and 3.65 with very practical criteria by students in terms of learning activities, ease of use, and benefits of use. Based on these, it can be concluded that the Plant Tissues Atlas developed is very valid and very practical.
\end{abstract}

Keywords: Atlas, Plant Tissue, Development Research

\section{Introduction}

Biology is part of science education that studies about living things and life phenomena. To understand the subject matter of biology, it is necessary to understand the concept of a very complex theory of biology subject. Biology learning material is basically in the form of facts, concepts, principles and theories, so that to prove the concept of biology lessons, practical activities in a laboratory are needed [1].

Learning through practicum stimulates students to be active in solving problems, think critically in analyzing existing problems and facts, and discover concepts and principles, so as to create more meaningful learning activities with a conducive learning atmosphere. Practicum is a very important part in a learning activity, especially learning science because it can improve the ability to organize, communicate, and interpret the results of observation. Science education must be supported by (practicum) [2].

Based on the results of researchers' interviews with biology teachers in class XI of SMAN 7 and SMAN 3 Padang, it was revealed that the biology practicum activities had been carried out in accordance with the 2013 curriculum. But in the process of observation and results, practicum of plant tissue is a practicum that is considered difficult by students.

Based on the results of researchers' observations of 28 students at SMAN 7 Padang, it was revealed that there were obstacles encountered during the practicum activities. Among these obstacles are, students are less skilled at making incisions and using microscopes properly and 
correctly, as a result the results of object incisions are not obtained properly or the plant tissue that will be observed is not clearly visible. On the other hand, there are several microscopes with moldy objective lenses, as well as insufficient time in observation.

In connection with the problems that have been raised, the temporary solution given by the teacher is to provide a preservation of plant tissue needed during the practicum, and to give instructions "searching" on the internet, to look for images of plant tissue that are observed, as a comparison image. However, students are less skilled in using microscopes properly and correctly, and when downloading comparative images from the internet, the images found are very varied and have inaccurate information.

The ineffectiveness of the solution provided, proves that teachers and students need supporting media in observing plant tissue, so students are motivated to get observations according to these guidelines. The unavailability of these media, has encouraged researchers to develop learning media in the form of Plant Tissues Atlas.

The Atlas of Plant Tissue contains a collection of photos of plant tissue incisions, which correspond to the tissue that students will observe. On the other hand, the lack of skilled students using a microscope, the Plant Tissue Atlas is equipped with instructions on how to use the microscope, and make plant incisions that are good and right, so that the Plant Tissue Atlas is expected to be a valid and practical guide in practicing plant tissue. Therefore, development research is carried out to produce Plant Tissues Atlas as a valid and practical learning medium for high school / MA students.

\section{Methods}

This development research is oriented to produce products, in the form of a Plant Tissues Atlas as a learning medium for high school / MA grade XI students. This was carried out in the Department of Biology, Faculty of Mathematics and Natural Sciences, Padang State University and SMAN 7 Padang.

Subjects in the study were two Biology Department lecturers at the Faculty of Mathematics and Natural Sciences UNP, one biology teacher and 28 students of class XI IPA SMAN 7 Padang. While the object of research is the Plant Tissues Atlas for high school / MA grade XI students.

The Atlas of the Plant Tissues, developed using three stages of the 4D development model [3], includes defining, designing, and developing. Whereas the fourth stage, namely distribution, was not carried out. At the definition stage, the terms of learning are determined, basic competencies and learning material are analyzed based on the 2013 Curriculum. This includes initial-end analysis, student analysis and task analysis. At the design stage, media selection and format selection are carried out. At the development stage, the validation and practicality testing of the Validation Tissues is carried out by the validator to see the feasibility and correctness of the concepts that have been made and provide judgments and suggestions based on statements in the validation questionnaire. Based on the validator's evaluation, the authors revised the Plant Tissues Atlas. Whereas practicality steps are carried out to find out the extent of the benefits and ease of use of the Plant Tissues Atlas by teachers and students by providing a practicality test questionnaire. Practicality steps include giving directions and explaining how to fill out the practicality questionnaire and then distributing the Plant Tissues Atlas to teachers and students. Furthermore, teachers and students use the Plant Tissues Atlas, and finally teachers and students 
are asked to fill out and provide suggestions and comments about the Plant Tissues Atlas by filling out the practicality questionnaire.

The data used in this study are primary data in the form of the results of validity and practicality, obtained through the provision of a validity and practicality questionnaire instrument for the research subjects. While the data analysis technique used is qualitative analysis to describe the validity and practicality of the Plant Tissues Atlas developed. The steps taken are as follows.

First, give a score of answers with four alternative answers arranged based on the Likert scale as follows.

$\begin{array}{ll}\text { STS (Strongly Disagree) } & \text { : Weight } 1 \\ \text { TS (Disagree) } & \text { : Weight } 2 \\ \text { S (Agree) } & \text { : Weight } 3 \\ \text { SS (Strongly Agree) } & \text { : Weight } 4\end{array}$

Then, determine class length or interval validity / practicality evaluation criteria using the qualitative data frequency method proposed, using the following Formula 1 [4].

$$
C=\frac{X_{n}-X_{1}}{K}
$$

Information :

C : = class length / interval

$\mathrm{Xn}:=$ Highest score

$\mathrm{X} 1:=$ lowest score

$\mathrm{K}:$ : Number of Classes

Then, based on the formula stated, the class length obtained for each criterion is 0.75 with the following ranges.

3.25-4.00: Very good

2.50-3.24: Good

1.75-2.49: Not Good

1.00-1.74: Very Bad

Then, the validity value of the product developed is determined by descriptive statistics in the form of a mean assessment using the modified formula shown in Formula 2 [4].

$$
V a=\frac{\sum_{i=1}^{n} A i}{n}
$$


Information :

$\mathrm{Va}=$ Average validity assessment results

$\mathrm{Ai}=$ Average validity assessment against criteria $\mathrm{i}$

$\mathrm{N}=$ Number of criteria

Then, the practicality value of the product being developed is determined by descriptive statistics in the form of a mean assessment using the formula in Equation 3 [4].

$$
V a=\frac{\sum_{i=1}^{n} A i}{n}
$$

Finally, after the average score criteria are obtained, the validity and practicality values of the products are grouped based on the modification of the evaluation criteria [5].

Validity assessment criteria:

3.25-4.00 = Very Valid

2.50-3.24 = Valid

$1.75-2.49=$ Invalid

1,00-1,74 = Very Invalid

Practicality assessment criteria:

$3.25-4.00=$ Very practical

$2,50-3,24=$ practical

$1.75-2.49=$ Not practical

1,00-1,74 = Very Impractical

\section{Results and Discussion}

The steps of the defining stage that have been carried out are as follows. The initial initial analysis is carried out to determine the main problems faced by students and teachers. The researcher made observations at SMAN 7 Padang by interviewing one of the Biology teachers, namely Mrs. Zailan Syarhani, M.Sc., revealed that the school had implemented practicum activities in accordance with the 2013 Curriculum for all classes at SMAN 7 Padang. Some obstacles were found when practicum took place. Class XI IPA1 which has difficulty in observing the structure of plant tissues and organs. Some of these obstacles such as, the results of observations are not visible, some microscopic objective lenses are moldy, students are less skilled in using microscopes and taking plant tissue preparations. Teachers and students do not have practicum guidelines for observing plant tissues such as the Plant Tissues Atlass.

Based on the analysis of students through interviews with teachers, it is known that students who sit in class XI have an age range between 15 to 17 years. Students have limited ability to use a microscope and make plant preparations, so students need a guide to help and improve the ability to observe plant tissue.

Task analysis is performed to determine the material that will be presented to students. This analysis includes content structure analysis, concept analysis and formulation of learning objectives.

1) Content Structure Analysis 
a) Core Competencies (KI)

KI.1 Appreciates and lives the teachings of the religion they hold.

KI.2 Demonstrates honest behavior, discipline, responsibility, caring (tolerance, mutual cooperation), polite, and confident, in interacting effectively

b) Basic Competence (KD)

3.3. Analyzing the relationship between cell structure in plant tissues and plant organ function

4.3. Presenting observational data on the anatomical structure of plant tissue to show its relationship with its location and function in bioprocess

c) Indicator Formulation

Learning indicators used as a basis in design are as follows:

3.3.1 Identify the types of tissue in plants

3.3.2 Analyze the function and structure of the meristem Tissues

3.3.3 Explain the structure of the adult Tissues

3.3.4 Analyze the relationship of structure and function of epidermal tissue

3.3.5 Analyzes the relationship of structure to the function of the parenchyma

Tissues

3.3.6 Analyze the relationship of structure to the function of the supporting Tissues

3.3.7 Analyzing the relationship of structure to the function of the transport Tissues

3.3.8 Analyzing the relationship of structure and function of secretory Tissuess

3.3.9 Analyzing the relationship of structure and function of cork Tissuess

3.3.10 Analyzing the relationship between the constituent tissues and their functions in plant organs

3.3.11 Explain the function of plant organs

3.3.12 Linking totipotency to plant tissue culture

3.3.13 Observing tissues in plant organs and sketching images of the results

4.3.1 Observation of transverse slices of monocotyledonous and dicotyledonous plants

4.3.2 Write reports on the results of tissue observations on plant organs

d) Learning Materials

Learning materials on the Atlas Tissues are: young Tissuess (meristem Tissuess) and adult Tissuess (permanent Tissuess).

2) Analysis of Learning Objectives

The learning objectives contained in the Plant Tissues Atlas developed include:

3.3.1. Students are able to explain the types of tissue in plants

3.3.2. Students are able to analyze the function and structure of the meristem Tissues

3.3.3. Students are able to explain the structure of adult Tissuess

3.3.4. Students are able to analyze the relationship of structure and function of epidermal tissue

3.3.5. Students are able to analyze the relationship between structure and function of the parenchyma Tissues

3.3.6. Students are able to analyze the relationship between structure and supporting Tissues function

3.3.7. Students are able to analyze the relationship between structure and function of the transport Tissues

3.3.8. Students are able to analyze the relationship between structure and function of secretory Tissuess 
3.3.9. Students are able to analyze the relationship between structure and function of cork Tissuess

3.3.10. Students are able to analyze the relationship between the constituent Tissuess and their functions in plant organs

3.3.11. Students are able to explain the function of plant organs

3.3.12. Students are able to associate the nature of totipotency in plant tissue culture

3.3.13. Students are able to observe the tissue in plant organs and sketch the results of the drawings

4.3.1. Students are able to observe transverse slices of monocot and dicot plants

4.3.2 Students are able to write reports on the results of tissue observations on plant organs

At the design stage, the Plant Tissues Atlas was designed in accordance with the 2013 curriculum. The steps undertaken at this stage were media selection and design of plant tissue atlas.

The media developed was Atlas Tissues media on the material of tissue structures and plant organs in class XI SMA / MA. The Atlas of Plant Tissue is made to function as a guide for practicum in plant tissues and organs in the laboratory.

Design of Plant Tissues Atlas, starting with the preparation of plant preparations in accordance with the curriculum analysis that has been done. Plant preparation was carried out manually in the botanical laboratory of the Department of Biology, Padang State University. Microscope photo display, the stages of using a microscope and how to make plant preparations are done manually. Plant preparations that get good observation forms are directly taken through the process of taking photos through a digital microscope, so that photos of plant tissues and organs observed in the "JPEG" format can be entered into Microsoft Office Power Point 2010 for editing. In general, the color of the Atlas Plant Tissues is green with the font type "Comic Sans MS".

The components of the Plant Tissues Atlass include coverings of the Plant Tissues Atlass, foreword, table of contents, list of tables, techniques for using microscopes, techniques for making plant preparations, and the results of photographs of plant tissue preparations. Figure 1.a, 1.b, 1.c, 2.a, 2.b, and 2.c displayed several pages of component design products that have been developed.

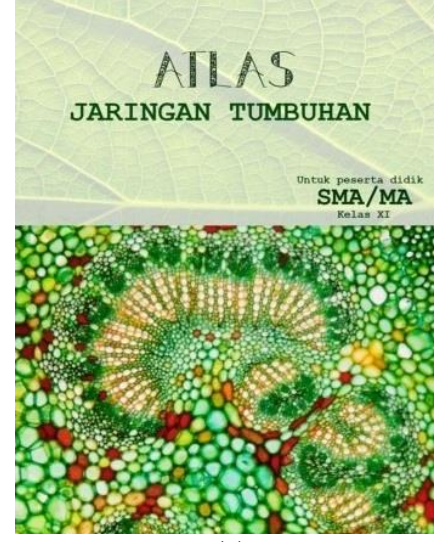

(a)

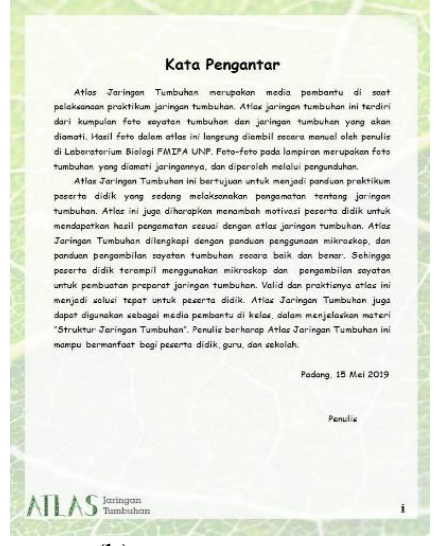

(b)

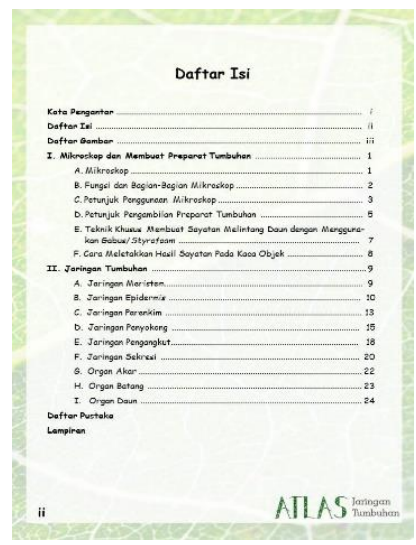

(c)

Fig. 1. a) Front cover, b) introduction, and c) list of contents of Plant Tissues Atlas. 


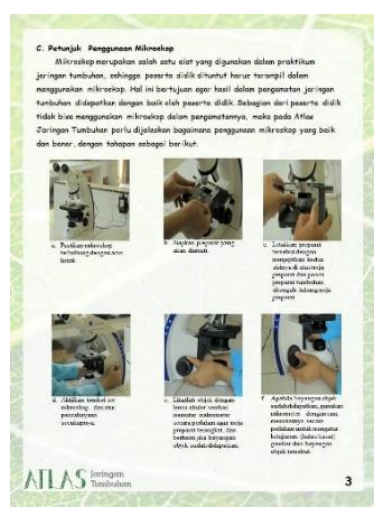

(a)

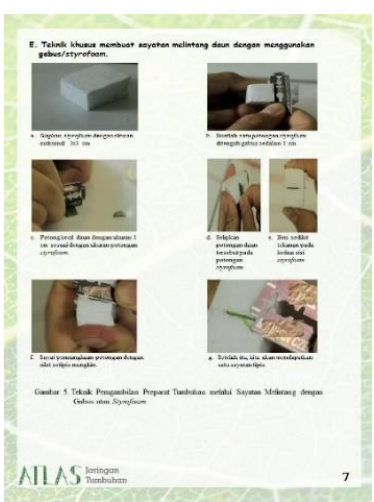

(b)

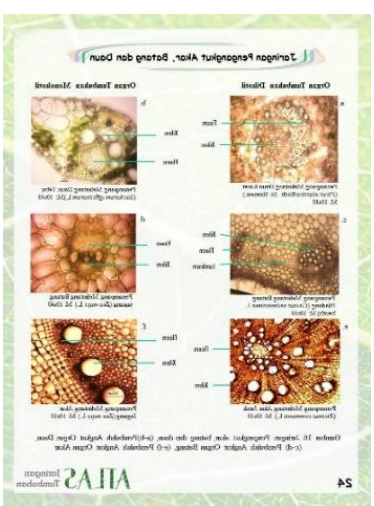

(c)

Fig. 2. a) Guide to use microscope, b) transverse incision making techniques, and c) and photographs of root, stem and leaf carrier tissuess of Plant Tissues Atlas.

The average validity test results from three validators can be seen in Table 1.

Table 1. Validity test results.

\begin{tabular}{rlcc}
\hline \multicolumn{1}{c}{ No. } & \multicolumn{1}{c}{ Aspects } & Validity Values & Criteria \\
\hline 1. & Feasibility Contents & 4,00 & Very Valid \\
2. & Language and Readability & 3,28 & Very Valid \\
3. & Serves & 3,89 & Very Valid \\
\hline \multicolumn{2}{c}{ Average } & 3,73 & Very Valid \\
\hline
\end{tabular}

In its development, the Plant Tissues Atlas has been revised based on the suggestions given by the validator. Some examples of improvements made are shown in Figure 3.a, 3.b, 4.a, and 4.b.

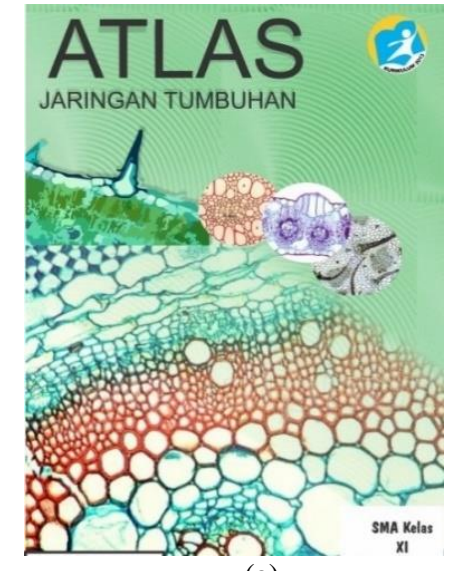

(a)

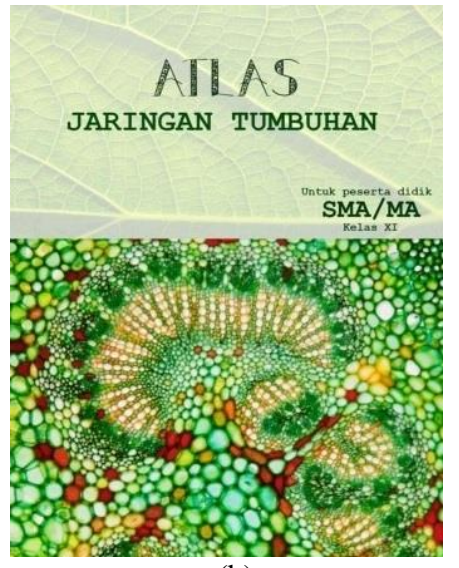

(b)

Fig. 3. Front cover, a) before repairing and b) after repairing. 


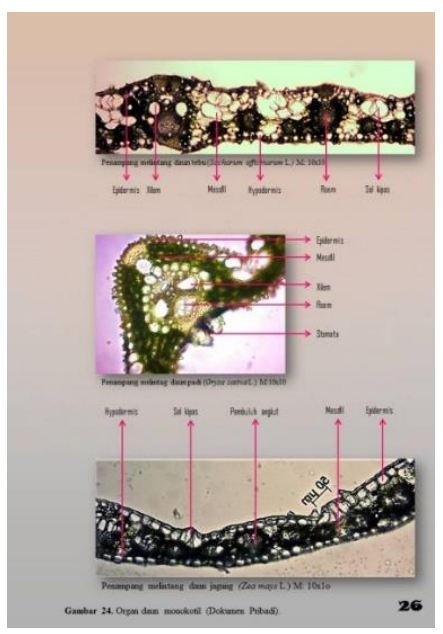

(a)

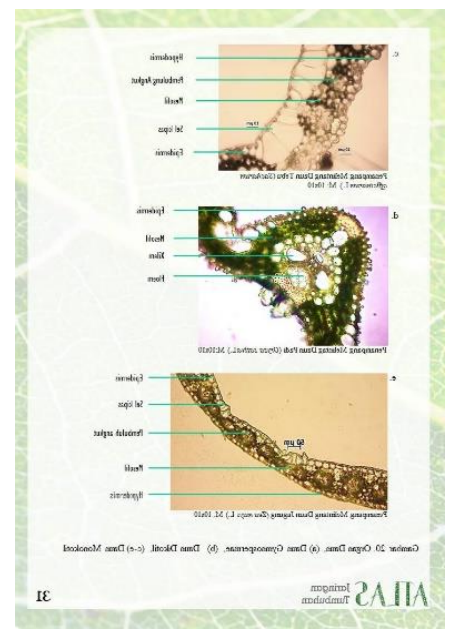

(b)

Fig. 4. Layout of plant tissue preparations, a) before repairing and b) after repairing.

The results of the practicality test analysis by teachers and students are shown in Table 2 .

Table 2. Practicality assessment results.

\begin{tabular}{|c|c|c|c|}
\hline \multirow{2}{*}{ No. } & \multirow{2}{*}{ Evaluation Aspects } & \multicolumn{2}{|c|}{ Result and Information } \\
\hline & & Teacher & Students \\
\hline 1. & Learning Activity & 3,89 & 3,64 \\
\hline 2. & Ease to Used & 3,80 & 3,68 \\
\hline 3. & Benefits of Using & 3,75 & 3,63 \\
\hline Avera & Practicality Value & 3,81 (very practical) & 3,65 (very practical) \\
\hline
\end{tabular}

Based on the results of the validity and practicality test of the Plant Tissues Atlas. In terms of the feasibility of the developed media content, it is classified as a very valid category with a value of 4.00. This shows that the Plant Tissues Atlas media developed has been in accordance with valid criteria, which means the media are in accordance with KI, KD, students' needs, media needs, correctness of content and compatibility with the applicable curriculum [6].

In terms of language and readability, the Plant Tissues Atlas developed was declared to be very valid with a value of 3.28. This shows that the media used use clear language, according to Indonesian rules, effective and efficient so that it can provide the right information. In good learning it is necessary to pay attention to the use of appropriate language and can be understood directly by students [7].

In the aspect of presentation, based on the questionnaire media validity of the Plant Tissues Atlas, an average value of 3.89 was obtained with very valid criteria. This means that the components of the Plant Tissues Atlas media have been presented in full in accordance with the order of the indicators developed. Material and pictures of plant preparations that are clear as atlas content will help students more easily observe plant tissue. The Atlas of Plant Tissue must have an interesting presentation, clear plant tissue preparation drawings, the layout of the image, and the color selection of the atlas is very influential. This is very important, because the 
development of instructional media must have an interesting presentation, because students first see from the appearance of a media that they use [8].

Overall, the average value of the validity results for the development of the Plant Tissues Atlas is 3.73 with very valid criteria, which means that the Atlas of the Plant Tissues has the right material and is in accordance with the needs of students. In this regard [9], in the development phase, learning media must have good material, with valid material criteria / validity and conformity with the needs of students. The Atlas of the Plant Tissues is very valid and meets the requirements to be used as a tool in achieving learning objectives and can be used in learning.

The results of practicality tests conducted on biology teachers and students can be seen from the aspects of learning activities, aspects of ease of use, and aspects of the benefits of use as follows.

a. Aspects of Learning Activities obtained from 3.89 teachers with very practical categories and from students 3.64 with very practical categories. This shows that the Plant Tissues Atlas media developed can be used and support learning activities.

b. The Ease of Use aspect obtained results from 3.80 teachers with very practical categories and 3.68 students with very practical categories. This shows that the Plant Tissues Atlas media developed has presented material in a clear, simple and overall easy to understand manner, so that learning objectives can be achieved by students.

c. The Benefit Aspect of the results obtained from the teacher 3.75 in the category of very practical and students 3.63 in the category of very practical. This means that in the tests conducted it appears that this media has the benefit of a beneficial use for users, namely teachers and students. Plant Tissues Atlas helps teachers in guiding practicum activities and is able to be a supporting medium in teaching in the classroom, while Plant Tissues Atlas helps in the process of observation in plant tissue and organ practicum, as well as being an effective means of understanding plant tissue material. Overall the practicality of the Learning Media Plant Tissues Atlas is 3.81 with a very practical category for teachers and 3.65 with a very practical category for students.

Plant Tissues Atlas which gets very valid and very practical value, proves that this learning media has the value of true material study and good product usage. The results obtained are also influenced by factors of product assessment instruments and research subjects who use these instruments. There are a number of learning media factors developed that can be valid and practical such as, assessment instruments have a direction of using instruments with clear meanings, words used in questionnaires are easily understood, indicator questions are in accordance with the material, precisely the allocation of time to work on the answers to the questionnaire, and the seriousness of students in filling out the questionnaire [10].

Invalid and practical Plant Tissues Atlas makes students motivated, to get the best observations in accordance with the results of observations on the Plant Tissues Atlas. Basically, the development of a learning product must be able to motivate students in implementing the learning process, especially when practicum activities [1].

\section{Conclusion}

Based on the results and discussions that have been carried out, it can be concluded, this development research, has been able to produce learning media in the form of Plant Tissues 
Atlas for grade XI students of SMA / MA, with very valid criteria, both from the appropriateness of content, language and readability and presentation as well as very practical, both from use in learning, utilization and benefits.

Based on research that has been done, it can be suggested that teachers can use the Plant Tissues Atlas as a learning medium and for researchers, it can be used as a reference or reference for the next morning of research.

Acknowledgments. The researcher thanked Mrs. Dra. Helendra, M.S., Ms. Ganda Hijrah Selaras, M.Pd. and Mrs. Dra. Zailan Syarhani, M.Si, who has been pleased to be the validator of this Plant Tissues Atlas. Thank you also researchers convey to the Principal and Biology Teachers and students of class XI IPA1, SMAN 7 Padang.

\section{References}

[1] Depdiknas.: Panduan pengembangan bahan ajar. Direktorat Jenderal Manajemen Pendidikan Dasar dan Menengah, Jakarta, Indonesia (2008)

[2] Rustaman, N., Dirdjosoemarto, S., Yudianto, S. A., Achmad, Y., Subekti, R., Rochintaniawati, D., Nurjhani, M.: Strategi belajar mengajar biologi. Universitas Negeri Malang, Malang, Indonesia (2005) [3] Thiagarajan, S., Semmel, D. S., \& Semmel, M. I.: Instructional development for training teachers of exceptional children. Indiana Univeristy Bloomington, Indiana, USA (1974)

[4] Sukardi: Evaluasi pendidikan prinsip dan operasionalnya. Bumi Aksara, Jakarta, Indonesia (2011)

[5] Nafiah, A., \& Purnomo, T.: Validitas lembar kegiatan siswa berbasis pendekatan salingtemas pada materi ekosistem kelas X SMA. Vol. 7, No. 1, pp. 1-8. BioEdu (2018)

[6] Lufri: Strategi pembelajaran biologi. Universitas Negeri Padang, Padang, Indonesia (2007)

[7] Supranto, J.: Statistik (teori dan aplikasi) edisi keenam. Erlangga, Jakarta, Indonesia (2000)

[8] Lufri, Ardi: Metodologi penelitian. UNP Press, Padang, Indonesia (2017)

[9] Zainiyati, H. S.: Pengembangan media pembelajaran berbasis ICT konsep dan aplikasi pada pembelajaran pendidikan agama Islam. Kencana, Jakarta, Indonesia (2017)

[10] Sukiman: Pengembangan media pembelajaran. Pedagogia, Yogyakarta, Indonesia (2012) 